DOI: $\underline{\text { https://doi.org/10.34069/AI/2021.42.06.18 }}$

How to Cite:

Pryimachenko, D., Ivanskyy, A., Lipynskyi, V., Matvieiev, O., \& Povoroznik, A. (2021). Counteracting illegal border crossing and human trafficking: comparative analysis. Amazonia Investiga, 10(42), 196-205. https://doi.org/10.34069/AI/2021.42.06.18

\title{
Counteracting illegal border crossing and human trafficking: comparative analysis
}

\section{Протидія незаконному перетину кордону та торгівлі людьми: порівняльне дослідження}

Received: May 29, 2021

\section{Abstract}

Freedom of expression, personal integrity, respect for honor and dignity, the right to an adequate standard of living, living conditions, and health care are among the fundamental human rights in the civilized world. Ignoring these opportunities in such criminal activities as human trafficking is an unacceptable phenomenon for today's reality. Yet, it exists. It is a challenge for researchers in various humanities, for policy- and decision-makers to create a system of effective counteraction to the violation of the inviolability of state borders and the fight against human trafficking. In this study, we focused on the relationship between the illegal border crossing and the analysis of the phenomenon of trafficking in persons, as well as their comparative characteristics and legislation to combat these phenomena. The subject of the study is public relations regarding illegal border crossing and human trafficking. Research methods are general scientific and special scientific methods, in
Accepted: July 12, 2021

Written by:

Dmytro Pryimachenko $^{80}$

https://orcid.org/0000-0001-8504-2450

Andriy Ivanskyy ${ }^{81}$

https://orcid.org/0000-0003-3500-7870

Vladyslav Lipynskyi ${ }^{82}$

https://orcid.org/0000-0002-4373-3330

Oleksii Matvieiev $^{83}$

https://orcid.org/0000-0002-1725-6489

Artem Povoroznik ${ }^{84}$

https://orcid.org/0000-0002-2286-8033

\begin{abstract}
Аннотація
Свобода волевиявлення, особиста недоторканність, повага до честі й гідності, право на достатній рівень життя, умов проживання та охорони здоров'я $є$ одними 3 фундаментальних прав людини в цивілізованому світі. Ігнорування цих можливостей при такій злочинній діяльності як торгівля людьми $€$ неприпустимим явищем для реалій сучасності. I тим не менше, воно існує. Для дослідників різних гуманітарних дисциплін, for policy- and decision-makers $\epsilon$ викликом створення системи ефективної протидії порушення недоторканності державних кордонів та боротьби з торгівлею людьми. У цьому дослідженні ми зосередили свою увагу на взаємозв'язку незаконного перетину кордонів та аналізі явища торгівлі людьми, a також ї порівняльній характеристиці i актах законодавства стосовно протидії цим явищам. Предметом дослідження є суспільні відносини щодо нелегального перетину кордону та торгівлі
\end{abstract}

\footnotetext{
${ }^{80}$ Doctor of Law, Professor, Vice rector of scientific work, University of Customs Service and Finance, Ukraine.

${ }^{81}$ Doctor of Law, Professor, Honored Jurist of Ukraine, Main scientist researcher of the Scientific research Institute of informatics and law of the NALS of Ukraine, Ukraine.

${ }_{82} \mathrm{Ph}$.D., Associate Professor, Head of the Educational and Scientific Institute of law and international legal relations of the University of Customs and Finance Ukraine, Ukraine.

${ }^{83}$ Head of Aggressive Action Department of the Main Operational and Search Department of the Odessa Border Detachment, Lieutenant Colonel Ukraine, Ukraine.

${ }^{84}$ Master of law, Chief of the subdivision of the state border guard service of Ukraine, Southern regional directorate, Odessa Border guard detachment, Separated check point Odessa Ukraine, Ukraine.
} 


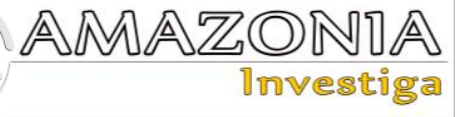

particular, systemic, historical, comparative, and statistical. The study characterized the genesis of international regulation of combating trafficking in persons; found commonalities and differences between the phenomena of illegal border crossing and trafficking in persons; described the signs of trafficking in persons, particularly, as a crime; provided relevant legislation regarding illegal border crossing and human trafficking.

Keywords: human trafficking, counteracting trafficking in persons, illegal migration, illegal border crossing, human rights.

\section{Introduction}

Unfortunately, forced movement of people across borders is not a new phenomenon, but the technological tricks used to conceal human trafficking and the illicit benefits of human exploitation make us wonder whether we are doing enough to address this issue (Belser, 2005; Feingold, 2005). When establishing restrictions on movement, determining the order of work, treatment, first of all, the collective interest is taken into account, the imperative method of legal regulation is applied, and the principles of public law are applied (Kharytonov, Kharytonova, Kolodin, \& Tkalych, 2020).

The very concept of human trafficking did not appear surprisingly. For example, the International Congress against Trafficking in Women, which took place in London in 1899 , officially declared the existence of a serious problem of human trafficking on a global scale (Limoncelli, 2010; Attwood, 2015, 2016; Lammasniemi, 2017; Panichevska, 2017). At the same time, guided by moral and ethical principles and ideals, the National Vigilance Association (NVA) began to play an important role in lobbying and further enforcing antislavery laws in England and Europe. Additionally, the International Bureau for the Suppression of the White Slave Traffic (the International Bureau) participated in the development of international agreements against white slavery, namely the Agreement for the Suppression of the White Slave Traffic in 1904 and the International Convention for the Suppression of the White Slave Traffic in 1910. In 1899, the London Conference of the International Bureau resulted in the development of international treaties. At that time, the International Bureau was campaigning for progressive reforms and engaging with government institutions. A resolution of the людьми. Методами дослідження є загальні наукові та спеціальні наукові методи, зокрема, системний, історичний, порівняльний та статистичний. У результаті дослідження було охарактеризовано генезу міжнародного регулювання протидії торгівлі людьми, знайдено спільні та відмінні риси між явищами нелегального перетину кордону та торгівлі людьми, наведена характеристика ознак торгівлі людьми, зокрема, цього явища як кримінального правопорушення.

Ключові слова: торгівля людьми, протидія торгівлі людьми, нелегальна міграція, незаконний перетин кордону, права людини.

International Congress held in 1899, chaired by the International Bureau and headed mostly by men, proposed a draft international agreement criminalizing human trafficking. In this regard, it also proposed measures to control borders and ports. At that time, England was the main hub of trade to the west. It was home to the main passenger ports of Hull, London, Southampton, and Liverpool. In these places, women could be recruited for sexual exploitation, brothel work, prostitution, etc. (Bartley, 2000; Laite, 2012). Much of this trafficking took place in London's East End, home to most Eastern European Jews, who at the time had the status of the largest group of migrants in the country. Cities like Manchester, Liverpool, and Leeds also trafficked people as they hosted a large number of migrants. Influenced by these processes, human rights groups emerged in England. One of them was the aforementioned NVA and the other was called to oversee the Jewish sector of anti-trafficking at home and abroad through the Gentlemen's Committee, which was part of the International Bureau (Attwood, 2016).

Following the establishment of the United Nations, the Convention for the Suppression of the Traffic in Persons was adopted in 1949 (Lukach, 2015, 2016). Despite its shortcomings, it has played a leading role in the international anti-trafficking regulation for a long time. Thus, there was a need for a new list of rules that would consider previous mistakes and respond to current challenges. The adoption of the Protocol to Prevent and Suppress Trafficking in Persons, Especially Women and Children (United Nations, 2000b) (also known as the Palermo Protocol), which supplemented the United Nations Convention against Transnational Organized Crime, is considered to be the beginning of modern regulation against human 
trafficking. It was adopted and opened for signature, ratification, and accession by General Assembly resolution 55/25 on November 15 , 2000 (Heinrich, 2010; Scarpa, 2010). Currently, this document is the most comprehensive international legal act regarding the fight against human trafficking.

As for the data, more than 230,000 Ukrainians have been trafficked since 1991 according to the International Organization for Migration (IOM). Unfortunately, it is one of the highest rates of modern-day slavery victims' origin in Europe (Official Website of the International Organization of Migration in Ukraine, 2021). Since 2000, more than 15,000 Ukrainians have applied to non-governmental organizations involved in the protection and assistance to victims of trafficking (Official Website of the Ministry of Education and Science of Ukraine, 2021). During 2000-2018, more than 15,300 victims of trafficking received assistance from IOM. $86 \%$ of those who turned to IOM for help in 2018, experienced human rights violations and labor exploitation in construction, industrial production, and agriculture. Characteristically, the perpetrators hardly used advertisements in newspapers, on the street, and through employment agencies to recruit victims of human trafficking. Recruitment occurred mainly at the place of residence through personal contact $(76 \%)$ and the Internet (8\%) (according to IOM statistics for 2018) (Mydlovets, 2019). According to the Ministry of Social Policy of Ukraine, in 2019, 185 citizens were officially recognized and registered as victims of human trafficking. Among them: 53 women, 119 men, and 13 children ( 3 boys and 10 girls). During this period, 65 people suffered from human trafficking in Ukraine, 120 people - from human trafficking abroad. 85 people suffered from labor exploitation, 40 people were involved in criminal activities, 37 people suffered from sexual exploitation, 17 people were used in armed conflicts, 3 people were used in pornography, 1 person was involved in begging, 1 person was a victim of mixed exploitation (labor and sexual exploitation), 1 child was trafficked to third parties.

The aim of the study was to analyze and characterize the relationship between the illegal border crossing and human trafficking, as well as the legal framework for combating these phenomena.

Given the above, as well as taking into account the scale, severity, the moral, ethical, and social content of the problem, in this study we examine the relationship between the illegal border crossing and the main signs of human trafficking as well as the legal norms to combat them.

\section{Theoretical Framework or Literature Review}

Over the past two decades, researchers have developed the necessary theoretical basis for analyzing the phenomenon of human trafficking. This problem is developed in the framework of various humanities such as political science, social theory, jurisprudence, economic theory, etc. There are thorough humanitarian studies in the field of human rights as well as international public and criminal law. For example, Feingold (2005) explored common myths about human trafficking in his report. The author concludes that simple solutions such as deporting victims or suggesting that poverty is the only reason of trafficking is not enough to combat it effectively. Borders tightening neither can help the issue. Thus, on the basis of analytical materials of international organizations and the scientific evidences, the author calls to consider a new complex framework on combating human trafficking rather than operating towards fast and simple decisions. Furthermore, Lukach (2015) analyzed the conceptual foundations of combating human trafficking in Ukraine in her article. From her standpoint, the regulation considering human trafficking should improve in the following aspects:

1) improving the mechanisms of legal influence and the work of law enforcement agencies;

2) paying attention to the legal status of persons and providing support to risk groups;

3) conducting educational work among the people, and;

4) protection and assistance to the victims of human trafficking. In her Ph.D. thesis, the author developed these ideas by exploring the institutional mechanisms of counteracting the global problem of the modern slave trade (Lukach, 2016).

Finally, Lammasniemi (2017) reviewed the historical experience of developing legislation to combat trafficking in persons. For example, she pays special attention to the genesis of English laws on combating trafficking in women.

\section{Methodology}

For this study, we used general scientific and special scientific methods such as systemic, historical, comparative, and statistical. 


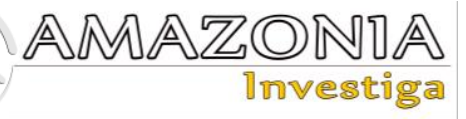

The systemic method presented such a complex phenomenon as human trafficking in the set of its interrelated features and forms of manifestation. In particular, it was demonstrated what constitutes trafficking in persons in political, socio-economic, and legal dimensions with their complementarity. Thus, to understand human trafficking as a system, it is necessary to explore it as a set of social relations at different levels of manifestation, in which a mandatory element is violence against victims of carriers and/or exploiters. The systemic method helps to determine how human trafficking occurs, what is related to it, what factors affect its intensity, what reasons it, etc. Using the systemic method, we can analyze the network of entities involved in trafficking. As an example, it can be the relationship between the recruiter, carrier, and exploiter (operator/recipient/beneficiary), the role of other entities in this chain, for example, corrupt locals or law enforcement agencies, third parties, etc. Moreover, the systemic method is useful for the study of the factors that influence the phenomenon of trafficking. Additionally, these factors must be investigated in their entirety and mutual influence on each other. We also used a systemic method to demonstrate how the antitrafficking regulation is organized. With its help, we pointed out that this regulation is characterized by a system of measures to prevent, counteract, and to protect and assist victims of trafficking.

We used the historical method to demonstrate the genesis of the legal regulation of combating trafficking in persons. In the introduction, we describe how human rights organizations for the victims of trafficking were born in England. They lobbied for the interests of victims and campaigned for progressive reforms to ban white slavery. The results of their activity were reflected in the further development of international legal instruments to combat trafficking in persons. It acquired modern features of unified legislation after the creation of the United Nations and the approval of relevant conventions culminating in the adoption of the Palermo Protocol in 2000 (United Nations, 2000b), which is currently the main international legal act to combat trafficking in persons.

We used the comparative method to figure out the differences and commonalities between the phenomena of illegal border crossing (transportation of persons across the state border) and human trafficking. In particular, we presented in the main part of the study that border crossing is often only part of a complex phenomenon of human trafficking. A significant discrepancy is that human trafficking is not always carried out through cross-border transport, which can be legal or illegal. In contrast, it is an entirely illegal phenomenon in the case of illegal border crossing. Moreover, illegal border crossing and human trafficking are different types of crime. Their objects of encroachment do not coincide since the object of the crime of illegal crossing of the state border is the state interest in terms of public order and migration rules (for example, the principle of inviolability of state border). The object of human trafficking is a specific person - its will, body or parts thereof, its health, honor and dignity, the ability to work. Thus, a common feature remains the objective side of these criminal offenses, which can manifest itself in the form of crossing the state border.

We used the statistical method to demonstrate the manifestation of trafficking in persons among the population of different social groups of Ukraine. In particular, statistics are contained in the introductory part of the study. In addition, we point out the importance of statistics on human trafficking, the complexity of its collection and processing. For example, the figures can indicate which type of exploitation is prevailing (labor exploitation), whether the intensity of trafficking increases over a set period, what the gender division of trafficking is, etc.

\section{Results and Discussion}

\section{What is the relation between illegal border crossing and human trafficking?}

According to Lukach (2016), there is a difference between illegal border crossing and human trafficking. They differ in several criteria, including the presence of consent, the fact of crossing the border, the nature of the client relationship between victims and perpetrators/carriers, the use of violence, the object of the crime, and its consequences. For example, illegal migration occurs with full or conditional consent and there is always the fact of illegal border crossing. Additionally, customer relationships arise between the carrier and the illegal migrant. Under such conditions, illegal migration is a violation of migration laws and regulations, but it is not a violent crime. Accordingly, it harms the national public interests and the legal order of the state. In regard of illegal migration, a person has a greater degree of freedom than a victim of trafficking, because migrants can act at their discretion. Their freedom is not limited by coercion or violence by the exploiter. In contrast, there is no room for 
informed consent when human trafficking takes place as the consent to sell oneself into slavery contradicts the basic principles of law, in particular, the invalidity of a transaction to alienate one's fundamental rights. There are additional factors such as manipulation, deception, fraud, psychological and physical or other coercion, which deny the informed consent of a person if one becomes a victim of trafficking. Crossing the border is not necessarily part of human trafficking as it can take place within the country. At the same time, crossing the state border can be both legal and illegal. Customer relations are formed between the "supplier" of the "product" and the exploiter. The ultimate goal of their relationship is to put the victim into operation. Human trafficking is a violent crime as violence accompanies this crime in various forms to force the victims to obey. The victim of this crime is a specific person. Its basic rights and freedoms are grossly violated, in particular, the rights to free movement and freedom of expression are restricted; the rights to a sufficient standard of living, living conditions, and health care are violated; there is a disrespect for its honor and dignity, etc. As a result, victims get in a subjugated position, which negatively affects their physical and mental health (Tsutsumi et al., 2008; Oram et al., 2012; Richards, 2014).

\section{What are the characteristics of human trafficking?}

Bales, Trodd \& Williamson (2011) point out the signs of the modern slave trade. According to their book, modern human trafficking is a globalized process. It is an illegal activity. It is short-termed compared to the past. At the same time, the ethnic character of the victims is not important nowadays. The "market price" for the exploitation of human resources is insignificant. It also brings high profits and is short-lived compared to how long slaves were in master's possession in the past.

According to Feingold (2005), there is a set of common misunderstandings in the public discourse regarding human trafficking. For example, the author questions the thesis that most victims of trafficking fall into sexual exploitation. He points out that labour trafficking is more common. In this sense, the argument is that the labour market is much larger and more dynamic than the sex market. It is also not to be expected that statistics clearly and reliably reflect the facts about the "end-use" of illegal labour. For example, Thai trafficking statistics did not consider men as victims of this crime. Additionally, a 2005 International Labour
Organization (International Labour Organization, 2005) study found that of the approximately 9.5 million victims of forced labor in Asia, less than $10 \%$ were trafficked for sexual exploitation (Belser, 2005; Feingold, 2005; Laczko \& Gozdziak, 2005; Danailova-Trainor \& Belser, 2006; Rafferty, 2007). According to this data, less than half of human trafficking worldwide accounted for sexual slavery. As Feingold (2005) points out, the legalization of prostitution can help in this regard only if a system of implementation of such reforms is provided, i.e., its proper enforcement, because blind faith in legalization and hopes that everything will be resolved on its own is not enough. Feingold (2005) continues that the authorities' efforts to strengthen border controls only exacerbate negative trends, as this leads to an increase in the demand for illegal traffic, which then has dire consequences for victims of various types of illegal exploitation. In the process of such travel, dependence on the carrier increases, which is an additional risk factor for becoming a victim of trafficking. Feingold (2005) indicates that it is possible to become a victim of trafficking in childhood or by being kidnapped. Although, it usually happens during travel and illegal border crossing. The profile of a typical trafficker is not definite. It can be truck drivers, locals, corrupt police officers. It is a small criminal activity rather than big criminal syndicates specialized in human trafficking. If large organized groups operate in this area, then this is not the main part of their business. According to Feingold (2005), the intensification of the prosecution of traffickers does not bring the desired effect since criminals are at the regional level, so another trafficker in the transportation chain easily takes the place of the convicted subject. Another myth is the expansion of sanctions, for example, in their international dimension. In this respect, the principle of encouragement applies, as strengthening sanctions against countries that do not respect human rights at all is counterproductive. In contrast, encouraging countries that work to combat human trafficking can yield positive results. In this regard, the declarative strengthening of sanctions in the absence of mechanisms for their implementation is also criticized. Feingold (2005) points out that it is not always effective to repatriate victims of trafficking, as they may again be at risk from those involved in their abuse. In this aspect, it is important to provide victims with a legal status, which they often do not have from birth (lack of legal status due to lack of legally registered birth, lack of citizenship). In conclusion, Feingold (2005) notes that poverty combined with horrific 


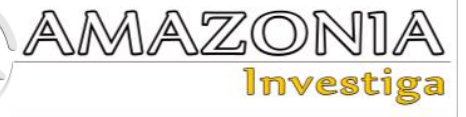

migration policies does not always lead to transnational trafficking, as this crime can take place within a country. For example, in China, Brazil, and Côte d'Ivoire, where cheap labor is valued in gold mines of Amazon (Brazil), cocoa harvesting plantations (Côte d'Ivoire), or forced marriage (China) (Lim, 1998; Laczko \& Gozdziak, 2005).

The phenomenon of human trafficking is complex. It may include various types of criminal activity. For example, when buyers receive the attributes of ownership on the person as their "thing". It occurs also when a person is sold for exploitation in customary slavery. Another example is the sale of a child for illegal adoption or the use of the embryo or human fetus for any gain. Alternatively, it can be trafficking in persons for illegal removal of their organs, etc. (Levchenko, Kovalchuk, Udalova et al., 2011).

Trafficking offenses are complex and multifaceted. It is not easy to solve them. Additionaly, surveillance tools require a systematic and comprehensive approach and interaction between different parts of law enforcement agencies. In this regard, operational and investigative activities carried out by border control authorities play a significant role (Biletsky, 2013). Nevertheless, one of the biggest problems remains the collection and analysis of reliable data on the phenomenon of human trafficking to expose criminals (Migration Data Portal, 2021).

There are several stages of trafficking in persons. The first is establishing control over a person by recruiting and/or kidnapping. In the second stage, a person is transferred to the place/country of destination. It is followed by the transfer to the exploiter and further exploitation (Koots \& Orlean, 2007).

Among the international institutions combating human trafficking are the following: the UN, Interpol, the Council of Europe, the OSCE, the EU. This rank also includes numerous nongovernmental organizations. State governments, represented by relevant ministries and law enforcement agencies, are also involved in this fight (Lukach, 2015).

Covering all regions and most countries, trafficking in persons is becoming transboundary. For example, there are some national legal systems in the European Union, and such diversity often causes problems when litigation transcends national borders. There are provisions on criminal liability for trafficking in persons in the criminal codes of most EU member states. Although, there are differences at the national level since national definitions may differ significantly both in terms of consent and border crossing. More and more EU countries are enacting specific provisions on assistance and protection for victims of trafficking. It allows them to stay (temporarily) in those countries and have access to refuge, medical, social, psychological, legal, or financial assistance. Some countries, such as Austria, Cyprus, the Netherlands, Germany, Lithuania, and Poland, have identified trafficking as a separate crime but limited it to prostitution or sexual exploitation (Lukach, 2016). The laws of most European countries, including the EU Member States, concerning prostitution (except for the Netherlands) are based on a prohibition model. Its main feature is that prostitution itself is not considered a crime, although criminal liability is provided for any "exploitation related to prostitution", which means the involvement of third parties. Recruitment for prostitution, aiding, abetting, pimping, brothel maintenance are prohibited.

\section{Norms of the national legislation of Ukraine on illegal border crossing and counteracting trafficking in persons}

The penalties for illegal border crossing are provided by Art. 332 of the Criminal Code (Law No. 2341-III, 2001) ("Illegal transfer of persons across the state border of Ukraine"). According to that norm, this crime means the organization of illegal transportation of persons across the state border of Ukraine, management of such actions or assistance in their commission by advice, instructions, provision of means, or elimination of obstacles. In contrast, under the provisions of Art. 149 of the Criminal Code (Law No. 2341-III, 2001), trafficking in person is prohibited, as well as recruitment, transfer, concealment, or receipt of a person committed for exploitation and with the use of coercion, abduction, deception, blackmailing, abuse of material, or other dependence of the victim, or its vulnerable condition, or bribery of a third party who controls the victim to obtain consent to exploitation. The note to the article explains what should be understood by exploitation of a person. Under the note, it includes all forms of sexual exploitation, porn business involvement, forced labor or forced provision of services, slavery or customs similar to slavery, enslavement, debt bondage, organ harvesting, human experiments without consent, adoption for profit, forced pregnancy or forced termination of pregnancy, forced marriage, forced beggarism involvement, 
involvement in criminal activity, involvement in armed conflicts, etc. The vulnerable condition is a condition of a person due to physical or mental properties or external circumstances, which deprives or limits the ability to realize actions (inaction) or manage them, make independent decisions, resist violent or other illegal actions, as well as the coincidence of difficult personal, family or other circumstances. Responsibility for recruiting, moving, hiding, transferring, or receiving a minor under Art. 149 of the Criminal Code (Law No. 2341-III, 2001) occurs regardless of whether such actions were committed with the use of coercion, abduction, deception, blackmailing, or vulnerability of the person or with the use or threat of violence, abuse of power, or committed by person on whom the victim was materially or otherwise dependent, or bribing a third party who controls the victim to obtain consent to exploitation. As follows from the comparison of the norms of Art. 332 and Art. 149 of the Criminal Code of Ukraine (Law No. 2341III, 2001), the main similarity between them is the manner of committing a criminal offense, which may be the movement of a person across the state border, as well as related organizational measures. However, trafficking in persons is not always carried out through cross-border movements.

The Law of Ukraine Law No. 3739-VI (2001) deals with such concepts as "combating trafficking in persons", "counteracting trafficking in persons", and "prevention of trafficking in persons" (Art. 1). According to this document, the fight against human trafficking means a system of measures taken in the framework of combating trafficking in persons. These measures are aimed at detecting the crime of trafficking in persons, in particular, if it is unfinished, as well as identifying the victims. The objectives also include identifying and prosecuting individuals and/or legal entities involved in trafficking. The prevention of human trafficking is a system of measures aimed at identifying and eliminating the causes and conditions that lead to trafficking in persons. Counteracting human trafficking means a system of measures aimed at overcoming trafficking in persons and providing assistance and protection to the victims. The law defines the concept of trafficking in persons as the conclusion of an illegal agreement involving a person as an object, as well as the recruitment, transfer, concealment, or receipt of a person, with the use of deception, fraud, blackmailing, vulnerable condition of a person, or with the use or threat of violence, abuse of power, material or other dependence of a person, which is recognized as a crime under
Art. 149 of the Criminal Code of Ukraine (Law No. 2341-III, 2001). The basic ideas on which the fight against human trafficking is based include ensuring human rights and freedoms, respect and tolerance for victims, the confidentiality of their personal data, voluntary assistance to victims and their non-discrimination, cooperation between authorities and law enforcement agencies, as well as public and international organizations (Art. 3.1 of the Law No. 3739-VI (2001)). If victims of trafficking or witnesses of trafficking are children, all actions applied to them are based on the principles set out in the Convention on the Rights of the Child (United Nations, 1989) and the Optional Protocol to the Convention on the Rights of the Child on the Sale of Children, Child Prostitution, and Child Pornography (Convention) (United Nations, 2000a) (Art. 3.2 of the Law of Ukraine No. 3739-VI (2001)). According to Art. 35 of this Convention, States Parties shall take all necessary measures at the national, bilateral, and multilateral levels to prevent the abduction of children, trafficking in children, or their smuggling for any purpose and in any form. Article 10 of the Optional Protocol (United Nations, 2000a) expands the provisions of Art. 35 of the Convention. If the age of a person is not determined and there are grounds to believe that this person is a child, it is considered so and the special protection is provided until the age is established (Art. 3.3 of the Law 3739-VI (2001)).

The development and implementation of policies in the field of combating trafficking in persons belongs to the powers of the state. Such areas include prevention of trafficking in persons, which covers informational and educational work and the efforts to reduce the demand for illegal exploitation of human resources. It also means bringing people involved in human trafficking to justice and providing assistance and protection to the victims (Art. 4 of the Law 3739-VI (2001)). Anti-trafficking actors include the head of state, the government, central and local executive bodies, local governments, foreign diplomatic missions of Ukraine, as well as institutions to assist victims of human trafficking. Enterprises, institutions, and organizations, regardless of the form of ownership, as well as public organizations and individuals can also join the struggle against human trafficking (Art. 5 of the Law 3739-VI (2001)). The national coordinator in the field of combating trafficking in persons is the Ministry of Social Policy of Ukraine (Art. 6.1 of the same Law 3739-VI (2001)). The powers of the government cover determining the procedure for the establishment and operation of the Unified 


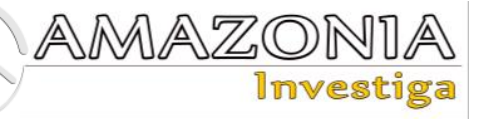

State Register of Crimes of Trafficking in Persons (Decree No. 303, 2012), which is administered by the Ministry of Internal Affairs (Art. 6.2, paragraph "c" of the Law No. 3739-VI (2001)). Moreover, the government has the right to approve the National Mechanism (Decree No. 783,2012 ) of interaction of subjects carrying out measures in the sphere of combating trafficking in persons, as well as to monitor its implementation (Art. 6.3, paragraph "b" of the Law 3739-VI (2001)). Additionally, the government establishes (Decree No. 660, 2012) the procedure for payment of one-time financial assistance to victims of human trafficking (Art. 6.4 of the Law No. 3739-VI (2001)).

When we talk about Ukraine authority system, it is worth mention that we have high level of corruption at all levels. Thus, considering the issue of prevention of human trafficking, it should be mentioned the UN Convention against Corruption (United Nations, 2003), which was adopted in New York on October 31, 2003. It establishes the necessary international legal framework to combat corruption offenses, in particular, identifies vectors of theoretical and practical developments in combating corruption (Kolomoiets, Tkalych, Melnyk, Panchenko, \& Tolmachevska, 2021).

\section{Conclusions}

Trafficking in persons is certainly a terrible phenomenon that violates the fundamental human rights on which modern life is based. To combat this criminal activity, the international community has developed a relevant document designed to provide legal regulation for the effective fight against human trafficking - the Protocol to Prevent, Suppress and Punish Trafficking in Persons, Especially Women and Children (United Nations, 2000b). The national legislation of some countries, particularly, Ukraine, has implemented relevant bills aimed at promoting the implementation of the ideas set out in the Protocol in the form of an effective system of measures to combat trafficking in persons at the national level. At the same time, concerning the phenomena of illegal border crossing and human trafficking, it can be noted that there are differences that give grounds to consider them as separate crimes with a common feature of their commission, which may manifest itself in the form of illegal transportation across borders. Finally, further collection and processing of statistics is important to help identify trends and patterns and to develop effective measures to combat these criminal offenses. Such actions include prevention, counteraction, protection and assistance to victims, and informational and educational work among the population.

\section{Bibliographic references}

Attwood, R. (2015). Stopping the Traffic: The National Vigilance Association and the International Fight Against the "White Slave" Trade (1899-1909). Women's History Review, 24(3), 325-350.

Attwood, R. (2016). Looking Beyond 'White Slavery': Trafficking, the Jewish Association, and the Dangerous Politics of Migration Control in England, 1890-1910. Anti-Trafficking Review, $7 . \quad$ Recovered from https://www.antitraffickingreview.org/index.php /atrjournal/article/view/203/200

Bales, K., Trodd, Z., \& Williamson, A.K. (2011). Modern Slavery: A Beginner's Guide. Simon \& Schuster

Bartley, P. (2000). Prostitution: Prevention and Reform in England, 1870-1914. London: Routledge

Belser, P. (2005). Forced Labor and Human Trafficking: Estimating the Profits. Geneva: International Labour Office. Recovered from https://bit.ly/36xuYbq

Biletsky, V.O. (2013). Operational Activities as a Component of Integrated Border Management. Public Administration: Improvement and Development, 7, 1-3. Recovered from https://bit.ly/3xNY95W

Danailova-Trainor, G., \& Belser, P. (2006). Globalization and the Illicit Market for Human Trafficking: an Empirical Analysis of Supply and Demand. Geneva: International Labour Office. In http://www.ilo.int/wcmsp5/groups/public/--dgreports/---

integration/documents/publication/wcms_08175 9.pdf

Decree No. 303, On Approval of the Regulations on the Establishment and Operation of the Unified State Register of Crimes of Trafficking in Persons. Bulletin of the Verkhovna Rada of Ukraine, Kyiv, Ukraine, April 18, 2012. Recovered from https://zakon.rada.gov.ua/laws/show/303-2012$\% \mathrm{D} 0 \% \mathrm{BF} \# \mathrm{n} 9$

Decree No. 660, On Approval of the Procedure for Payment of One-Time Financial Assistance to Victims of Trafficking in Persons. Bulletin of the Verkhovna Rada of Ukraine, Kyiv, Ukraine, July 25, 2012. Recovered from https://zakon.rada.gov.ua/laws/show/660-2012$\% \mathrm{D} 0 \% \mathrm{BF} \# \mathrm{n} 9$

Decree No. 783, On the Statement of the Order of Interaction of Subjects Counteracting Trafficking in Persons. Bulletin of the Verkhovna Rada of Ukraine, Kyiv, Ukraine, 
August 22, 2012. Recovered from https://zakon.rada.gov.ua/laws/show/783-2012$\%$ D0\%BF\#n10

Feingold, D.A. (2005). Human Trafficking. Foreign Policy, 26-32. Recovered from https://documentation.lastradainternational.org/l sidocs/feingold_think_again_human_tra_0109.p df

Heinrich, K.H. (2010). Ten Years After the Palermo Protocol: Where Are Protections for Human Trafficking? Human Rights Brief, 18(1), 2-5.

In http://digitalcommons.wcl.american.edu/hrbrief/ vol18/iss $1 / 1$

International Labour Organization (ILO). (2005). Forced Labour in Asia. ILO Fact Sheets on Forced Labour in Asia, 1-4. Recovered from https://ecommons.cornell.edu/bitstream/handle/ 1813/99623/Forced_labor_no_17_Forced_labo ur_and_human.pdf? sequence $=1$

Kharytonov, E., Kharytonova, O., Kolodin, D., \& Tkalych, M. (2020). The Covid-19 Pandemic and the Rights of the Individual in Terms of Private and Public Law. Ius Humani. Law Journal, 9(2), 225-250. Recovered from https://doi.org/10.31207/ih.v9i2.253

Kolomoiets, T., Tkalych, M., Melnyk, P., Panchenko, B., \& Tolmachevska, Y. (2021). Combating Corruption in Sport: Legal Aspect. Retos, 41, 746-755. Recovered from https://recyt.fecyt.es/index.php/retos/article/vie w/86975

Koots, V., \& Orlean, A. (2007). Prosecutorial Means of Combating Human Trafficking. Kyiv: Varta. Recovered from https://www.osce.org/files/f/documents/d/d/758 90.pdf

Laczko, F., \& Gozdziak, E.M. (2005). Data and Research on Human Trafficking. International Organization for Migration

Laite, J. (2012). Common Prostitutes and Ordinary Citizens: Commercial Sex in London, 1885-1960. London: Palgrave Macmillan. ISBN 978-0-230-35421-0. Recovered from https://www.palgrave.com/gp/book/9780230230 545

Lammasniemi, L. (2017). Anti-White Slavery Legislation and Its Legacies in England. AntiTrafficking Review, 9, 64-76. Recovered from https://www.antitraffickingreview.org/index.php /atrjournal/article/view/264/253

Law No. 2341-III, Criminal Code of Ukraine. Bulletin of the Verkhovna Rada of Ukraine, Kyiv, Ukraine, April 5, 2001. Recovered from https://zakon.rada.gov.ua/laws/show/2341 14/conv\#n2649

Law No. 3739-VI, On Counteracting Trafficking in Persons. Bulletin of the Verkhovna Rada of Ukraine, Kyiv, Ukraine, September 20, 2011.
Recovered from https://zakon.rada.gov.ua/laws/show/373917\#Text

Levchenko, C., Kovalchuk, L., Udalova, O. et al. (2011). Socio-Pedagogical Bases of Counteracting Human Trafficking and Children Exploitation. Kyiv: "Ukraine" Agency

Lim, L.L. (1998). The Sex Sector: The Economic and Social Bases of Prostitution in Southeast Asia. Geneva: International Labour Organization Limoncelli, S.A. (2010). The Politics of Trafficking: The First International Movement to Combat the Sexual Exploitation of Women. Stanford University Press

Lukach, N.M. (2015). Conceptual Basis of Preventing and Combating Human Trafficking in Ukraine. Scientific and Theoretical Almanac Grani, 18(7), 75-78. Recovered from https://grani.org.ua/index.php/journal/article/do wnload/249/236

Lukach, N.M. (2016). Conceptual Principles and Institutional Mechanisms for Counteracting the Global Problem of Human Trafficking (doctorate thesis). Ivan Franko National University of Lviv, Lviv.

\section{In} http://www.chnu.edu.ua/res/chnu/chnu_news/Fe bruary/Dyser_LUKACH.pdf

Migration Data Portal. (May 6, 2021). Human Trafficking. Recovered from https://migrationdataportal.org/themes/humantrafficking

Mydlovets, I. (February 28, 2019). Human Trafficking in Ukraine. A Review. Recovered from

https://mon.gov.ua/storage/app/media/pozashkil na/protydia-torgivli-luydmy/4-2019.ppt

Official Website of the International Organization of Migration in Ukraine. (2021). Counteracting Human Trafficking. Recovered from https://iom.org.ua/ua/protidiya-torgivlilyudmi

Official Website of the Ministry of Education and Science of Ukraine. (2021). Counteracting Human Trafficking. Recovered from https://mon.gov.ua/ua/osvita/pozashkilnaosvita/vihovna-robota-ta-zahist-pravditini/protidiya-torgivli-lyudmi

Oram, S., Stöckl, H., Busza, J., Howard, L.M., \& Zimmerman, C. (2012). Prevalence and Risk of Violence and the Physical, Mental, and Sexual Health Problems Associated with Human Trafficking: Systematic Review. PLoS Medicine, 9(5), e1001224. Recovered from https://doi.org/10.1371/journal.pmed.1001224 Panichevska, A.V. (2017). White Slavery as One of the Most Common Transnational Crimes. Young Scientist, 11(51), 972-975. In http://molodyvcheny.in.ua/files/journal/2017/11 1235.pdf 


\section{AMAZONZA \\ 1nvestiga}

Rafferty, Y. (2007). Children for Sale: Child Trafficking in Southeast Asia. Child Abuse Review, 16, 401-422. Recovered from https://doi.org/10.1002/car.1009

Richards, T.A. (2014). Health Implications of Human Trafficking. Nursing for Women's Health, 18(2), 155-162.

Scarpa, S. (2010). Trafficking in persons: Modern Slavery. Oxford University Press

Tsutsumi, A., Izutsu, T., Poudyal, A.K., Kato, S., \& Marui, E. (2008). Mental Health of Female Survivors of Human Trafficking in Nepal. Social Science \& Medicine, 66(8), 1841-1847. Recovered from https://cdn.icmec.org/wpcontent/uploads/2020/07/MH-of-femalesurvivors-of-human-trafficking-in-NepalTsutsumi-2008.pdf

United Nations. (2003). Convention against Corruption. Retrieved from https://www.unodc.org/unodc/en/treaties/CAC/.
United Nations (UN). (1989). Convention on the Rights of the Child. Recovered from https://www.ohchr.org/en/professionalinterest/p ages/crc.aspx

United Nations (UN). (2000a). Optional Protocol to the Convention on the Rights of the Child on the Sale of Children, Child Prostitution and Child Pornography. Recovered from https://www.ohchr.org/en/professionalinterest/p ages/opsccrc.aspx

United Nations (UN). (2000b). Protocol to Prevent and Suppress Trafficking in Persons, Especially Women and Children. Recovered from

https://www.unodc.org/documents/treaties/Spec ial/2000_Protocol_to_Prevent_2C_Suppress_an d_Punish_Trafficking_in_Persons.pdf 